\title{
Identifying Resistance to Crown Rot Caused by Colletotrichum gloeosporioides in Strawberry
}

Jozer Mangandi, Natalia A. Peres, and Vance M. Whitaker; Gulf Coast Research and Education Center, University of Florida, Wimauma 33598

\begin{abstract}
Mangandi, J., Peres, N. A., and Whitaker, V. M. 2015. Identifying resistance to crown rot caused by Colletotrichum gloeosporioides in strawberry. Plant Dis. 99:954-961.

Resistance to Colletotrichum crown rot (CCR, caused by Colletotrichum gloeosporioides) among commercial strawberry cultivars is variable, and increasing host resistance is a goal of the strawberry breeding program at the University of Florida. Twenty-eight accessions of Fragaria virginiana and $F$. chiloensis, the progenitor species of the cultivated strawberry $(F . \times$ ananassa $)$, were evaluated for CCR resistance on artificially inoculated plants in a field trial, along with cultivars and breeding selections. Accessions PI 612320, PI 612323, and PI 551736 and selections FL 10128 and FL 10-129 had no mortality in either of two seasons. The most

susceptible genotypes had mortality between 75 and $100 \%$. In a separate growth-chamber evaluation, seven genotypes were inoculated by spraying a spore suspension onto the crown or by injecting the suspension directly into the crown tissues. Mortality was higher using the injection method but the ranking of the genotypes was similar for both methods, indicating that resistance is expressed within crown tissues. Among the seven genotypes, selections FL 10-128 and FL 10-129 had the lowest mortality regardless of inoculation method, illustrating that a high level of resistance can be found within the cultivated germplasm.
\end{abstract}

From tropical to temperate zones around the world, Colletotrichum spp. cause economic losses in commercial crops. Legumes, cereals, and a variety of perennial crops are susceptible to Colletotrichum infections, which can occur in many plant organs, including roots, leaves, stems, flowers, and fruit (2). The cultivated strawberry (Fragaria $\times$ ananassa Duch.) is a high-value crop, cultivated in more than 75 countries, that is susceptible to fungi of this genus. The United States is the largest producer of strawberry, most of which is grown in California and Florida (27).

In Florida fruiting fields, Colletotrichum crown rot (CCR, caused by Colletotrichum gloeosporioides (Penz.) Penz. \& Sacc.) is a vascular disease causing necrosis in crown tissues followed by sudden plant collapse and death. Other Colletotrichum spp. can also infect strawberry crowns; however, $C$. gloeosporioides has been recovered most frequently from diseased plants in Florida $(18,33)$. Plant losses from CCR of up to $5 \%$ are observed frequently on Florida production fields (23), though more serious outbreaks have occurred during the last decade in which entire fields have been lost. Inoculum often originates with transplants produced in nurseries in the southern United States, such as those in North Carolina (23). However, inoculum can also come from hosts of $C$. gloeosporioides surrounding strawberry fields $(24,36)$. Plant mortality in the fruiting field usually occurs at the beginning (October and November) and end (March and April) of the Florida strawberry season, when warmer temperatures facilitate disease development. Nevertheless, when infection occurs early in the season, plant collapse may continue even during the colder months (December to February).

Chemical control of CCR is challenging because the curative activity of fungicides, such as the strobilurins azoxystrobin and pyraclostrobin, is limited to $24 \mathrm{~h}$ after infection and can only prevent about $50 \%$ of infected plants from dying (23). Preventive applications of the fungicide captan throughout the growing season can reduce the spread of the pathogen from infected plants or alternative hosts within or surrounding fields but are ineffective if transplants

Corresponding author: V. M. Whitaker; E-mail: vwhitaker@ufl.edu

Accepted for publication 29 December 2014.

http://dx.doi.org/10.1094/PDIS-09-14-0907-RE

(C) 2015 The American Phytopathological Society arrive infected from nurseries (23). As an alternative for CCR management, strawberry growers in Florida are advised to use resistant cultivars. Most of the cultivars utilized in Florida's commercial production were developed at the University of Florida (UF); however, resistance to CCR among these cultivars is variable, with some such as 'Florida Elyana' considered moderately resistant and some such as 'Strawberry Festival' considered highly susceptible (4-8). CCR also causes plant death during the breeding operation. Controlled pollinations, seedling production, and maintenance of mother plants are performed in greenhouses in Florida, where most losses of breeding material are due to CCR, with the highest incidence during the summer months. Additionally, strawberry fruit production in Florida and, thus, planting of fruiting fields has been shifting to earlier dates to take advantage of high market prices in late November and early December. Transplants established during late September are exposed to the hot and humid conditions conducive to CCR development for a longer period than those planted during the more traditional planting period of mid-October.

Variation in the aggressiveness within the pathogen population may result in increased disease incidence in a particular season in production fields. Several C. gloeosporioides isolates were utilized to evaluate CCR resistance in commercial cultivars in Florida and some caused higher plant collapse and mortality than others (22). However, no significant interaction with cultivar was observed, suggesting that resistance to CCR in strawberry is not isolate specific. Also, genetic parameters for resistance to CCR were obtained recently from a strawberry population evaluated in Florida and North Carolina. The population originated from diverse parentage, including cultivars and selections from the UF and North Carolina State University (NCSU) breeding programs (26). The study showed that an increase in resistance to CCR of approximately $74 \%$ over the population mean is possible by selecting and deploying the most resistant genotypes from the most resistant families. Taken together, these studies indicate that increased resistance to multiple $C$. gloeosporioides isolates is possible through traditional breeding. However, even the most resistant genotypes released to date have shown some level of plant collapse.

Improving disease resistance by introduction of genes from wild crop relatives has been widely reported $(11,20)$. In strawberry, the octoploid progenitor species Fragaria virginiana and $F$. chiloensis have been utilized for improvement of cultivated strawberry. Various traits from these wild species have been successfully transferred into 
commercial breeding programs $(16,32)$. The most-utilized genotypes have been those of the Fragaria supercore collection (United States Department of Agriculture-Agricultural Research Service National Clonal Germplasm Repository, Corvallis, OR), consisting of more than 30 accessions representing the diversity of the two species from North and South America (12). The collection has already been screened for resistance to multiple pests and diseases $(20,21,28)$. Lewers et al. (21) screened 22 supercore accessions by spraying plants with spore suspensions of three Colletotrichum spp., including $C$. gloeosporioides. Accessions of both $F$. chiloensis and $F$. virginiana showed some level of resistance to the $C$. gloeosporioides isolate tested. However, the scale used in this evaluation utilized foliar symptoms as well as plant collapse in determining resistance or susceptibility to C. gloeosporioides. Therefore, resistance to CCR alone cannot be determined with confidence from this study, because the relationship between foliar infection and crown infection in strawberry has not been determined.

Given the importance that CCR has for strawberry breeding and production in Florida, further investigation is needed to identify and characterize potential sources of resistance. The main objective of this study was to evaluate UF breeding germplasm and the supercore collection for resistance to CCR by observing plant collapse in a study of inoculated plants under commercial conditions. A subset of genotypes was evaluated by injecting a $C$. gloeosporioides spore suspension into the crown tissues to examine whether resistance is expressed directly in the crown.

\section{Materials and Methods}

Field screening. Twenty-eight supercore accessions were evaluated in each of two seasons (2012-13 and 2013-14) for resistance to CCR. Four commercial cultivars were utilized as standards, because their resistance or susceptibility to C. gloeosporioides had been previously documented. Florida Elyana (7) and 'Treasure' (9) are both moderately resistant to CCR whereas Strawberry Festival (6) and 'Camarosa' (36) are susceptible. Additionally, two previously evaluated breeding selections from the UF (FL 10-128 and FL 10129) were included because they exhibited an unusually high level of resistance (26). All genotypes were maintained in 3.8-liter pots in a greenhouse at the UF Gulf Coast Research and Education Center (GCREC), Wimauma, FL. During July through August in both years, plants were allowed to produce runner tips, which were collected in early September and rooted in 40-cell trays filled with soilless media (Fafard 2 Mix; Fafard, Agawam, MA). Before planting in the trays, runner tips were dipped in a pesticide mix containing $4.5 \mathrm{~g}$ of Captan $50 \mathrm{WP}$ ( $2.2 \mathrm{~g}$ of captan; Arysta LifeSciences, Cary, NC), $0.5 \mathrm{ml}$ of QuadrisTop (0.09 $\mathrm{ml}$ of azoxystrobin $+0.06 \mathrm{ml}$ of difenoconazole; Syngenta, Greensboro, NC), and $5 \mathrm{ml}$ of Topsin M WSB $(3.5 \mathrm{ml}$ of thiophanate-methyl; United Phosphorus Inc., King of Prussia, PA) per 3.8 liters of water to control fungal infections; and $1.8 \mathrm{~g}$ of Savey 50 DF (0.9 g of hexythiazox; Gowan Company, Yuma, AZ) for mite control. After dipping, the pesticide mix was allowed to dry on the foliage before placing the tips under intermittent mist for 10 days for establishment, followed by 4 to 5 weeks for growth and root development. Production of rooted tips was performed in a greenhouse where light and temperature were not controlled, except by an automatic cooling system which activated when temperatures raised above $21^{\circ} \mathrm{C}$. Rooted tips were transplanted to the field on 19 October 2012 and 18 October 2013 and overhead irrigation was applied for 2 days for establishment. Plants were allowed to grow for 4 more weeks before inoculation on 12 November 2012 and 11 November 2013. Current commercial practices for annual strawberry plasticulture in Florida were followed to prepare and maintain the field experiment, with the exception that no fungicides to control C. gloeosporioides were applied. For each genotype, plots consisted of three to five plants and were arranged in a randomized complete block design, with each of four raised beds serving as blocks.

C. gloeosporioides isolate 97-15A, maintained in the GCREC pathogen culture collection, was utilized for inoculations. This isolate was obtained in 1997 from an infected crown of 'Sweet Charlie' and has been used in previous CCR evaluations (24). The fungal isolate was grown on potato dextrose agar (PDA) at $24^{\circ} \mathrm{C}$ and sporulated profusely after 7 to 10 days. Plates were flooded with sterile distilled water, the spore suspension was passed through cheesecloth to remove dislodged mycelia, and the suspension was adjusted to $1 \times$ $10^{5}$ conidia/ml. Each plant was inoculated with $2 \mathrm{ml}$ of the spore suspension with a handheld sprayer by placing the nozzle approximately $2 \mathrm{~cm}$ above the crowns. Inoculations were performed late in the afternoon and intermittent mist was applied for about $4 \mathrm{~h}$ until sunset the day of inoculation to maintain free water.

Plant mortality was recorded for 21 weeks starting 1 week after inoculation. Mortality was recorded when $75 \%$ or more of the leaf canopy had wilted and collapsed onto the bed surface. The area under the disease progress curve (AUDPC) was calculated for each plot according to Campbell and Madden (3). For the statistical analysis, the AUDPC values were ranked using the Rank procedure of SAS (version 9.3; SAS institute, Cary, NC). The ranks were then analyzed using the Mixed procedure with the ANOVAF and MIVQUE0 options to generate $P$ values for the effect of blocks and genotypes in the model, as described by Shah and Madden (29). Genotypes were compared with commercial cultivars by rank values using orthogonal contrasts at $P<0.05$.

Percent plant mortality at the last evaluation ( 21 weeks after inoculation [wai]) for each plot was transformed to the arcsine square root and analyzed using the Mixed procedure. Seasons and genotype effects were considered fixed whereas blocks within season were considered random. Taxa were determined for each genotype, as described by Kennedy et al. (19), to model different variances grouped by taxon. Genotype means were separated using Fisher's protected least significant difference test $(P<0.05)$. Analysis of AUDPC and transformed mortality percentages at 21 wai showed significant genotype-season interactions $(P<0.0001)$; thus, seasons were analyzed separately for both variables.

Genotypes that had 0 to $10 \%$ mortality at the end of both seasons were evaluated to determine colonization of crown tissues. Plants were dug from the soil, leaves and roots were removed, and crowns were stored at $4{ }^{\circ} \mathrm{C}$ in plastic bags until evaluation. Crowns were cut vertically into several pieces and the percentage of necrotic tissue on the cut surfaces was estimated for each plant based on a 5\% increment scale. C. gloeosporioides colonization was confirmed by isolating from necrotic boundaries on PDA supplemented with $0.1 \mathrm{~g}$ of streptomycin and $0.25 \mathrm{~g}$ of ampicillin per liter of media. Isolations were made from at least two crowns from each plot and also from different lesions when crowns had infections at multiple sites.

Crown resistance. Plants of seven genotypes were obtained from tissue culture to ensure disease-free stock and maintained as mother plants in 3.8-liter pots. The known susceptible cultivars Strawberry Festival (6) and Camarosa (36), the moderately resistant Florida Elyana (7) and Treasure (9), the UF selections FL 10-128 and FL 10-129 (26), as well as $F$. virginiana PI 612486 (26), were used to determine whether host resistance to CCR is active within crown tissues. Plug plants were established from runners of tissue-cultured mother plants following the method outlined above. After establishment, plug plants from the selected genotypes were transplanted to $10-\mathrm{cm}$ pots and grown for 4 weeks before inoculation.

To evaluate the presence of resistance in crown tissues, plants were inoculated with isolate $97-15 \mathrm{~A}-\mathrm{GFP}$, a clonal colony from the isolate utilized in the field study that was transformed with a green fluorescent protein (GFP) gene (J. Mangandi, K. M. Folta, N. A. Peres, and V. M. Whitaker, unpublished). Inoculum was produced as described above, with the exception that the isolate was grown in PDA supplemented with hygromycin B (MP Biomedicals LLC, Solon, OH) at $100 \mathrm{mg} / \mathrm{ml}$. Inoculations were performed in a growth room kept between 23 and $29^{\circ} \mathrm{C}$. Five plants per genotype were inoculated by spraying $1 \mathrm{ml}$ of spore suspension adjusted to $1 \times 10^{6}$ conidia/ml with a spray bottle, positioning the nozzle approximately $2 \mathrm{~cm}$ above the crown. A second set of five plants was inoculated by injecting $10 \mu \mathrm{l}$ of the spore suspension directly into the crown using a $25 \mathrm{G}(0.5 \mathrm{~mm}$ in outer diameter by $25 \mathrm{~mm}$ in length) syringe. The experiment was repeated twice with plants of each genotype-inoculation method combination, randomized in three blocks for the first experiment and in two blocks for the second. In follow-up inoculations using selected 
genotypes to confirm the results, water-injected and noninoculated controls were also included. As in the field experiment, crowns of plants that survived were dissected to examine for internal necrosis.

Percent mortality was calculated for each genotype 26 days after inoculation (dai) for the first experiment and 52 dai for the second experiment. Percent mortalities were transformed to the arcsine square root. Transformed data from both experiments were combined and analyzed using the Glimmix procedure of SAS. Experiment replication, genotype, and inoculation method were considered fixed effects whereas blocks were considered random effects within experiment replications. Genotype means were separated using Fisher's protected least significant difference test $(P<0.05)$.

\section{Results}

Field screening. The overall incidence of plant collapse was higher during the 2012-13 season (57\%) than during the 2013-14 season (43\%), also shown by a significant season effect in the model $(P=$ $0.001)$. The first plants showing $>75 \%$ collapsed canopy were observed at 3 and 4 wai (3 December 2012 and 9 December 2013, respectively). The model revealed a highly significant genotype effect $(P<0.0001)$, suggesting significant differences among genotypes for resistance to CCR. The significant genotype-season interaction $(P<0.0001)$ indicates that, for some genotypes, mortality varied across seasons.

Mortality percentages in both seasons ranged from 0 to 100 whereas AUDPC values were 0 to 109.9 and 0 to 85.7 for the 2012-13 and 2013-14 seasons, respectively (Tables 1 and 2). In general, more accessions of $F$. virginiana than $F$. chiloensis had mortality percentages similar to or higher than the commercial cultivars. The $F$. chiloensis accessions were highly susceptible and most had mortalities higher than $75 \%$ in both seasons. In contrast, among the $F$. virginiana accessions, various genotypes had mortalities less than $10 \%$. Compared with commercial cultivars, several genotypes had mortality percentages lower than the commercial standards, except when compared with Florida Elyana. Mortality of Florida Elyana was low in both seasons $(8.3$ and $15.0 \%)$ but even genotypes with zero mortality were not significantly different from Florida Elyana. This trend was also observed for the AUDPC values; however, because the time necessary to reach maximum mortality was not the same for all genotypes, changes in the rankings were observed. For instance, in the 2012-13 season, mortality at 21 wai of PI 612570 was $15 \%$ whereas Treasure had $30 \%$ plant collapse (Table 1). The AUDPC value of PI 612570, however, was larger (9.2) than that of Treasure (5.2).

F. virginiana accessions PI 612324 and PI 612501 had mortalities of $\leq 10 \%$ in both seasons whereas PI 612320 and PI 612486 had zero mortality in one season but some plants (5 and $10 \%$, respectively) collapsed in the other. Five genotypes ( $F$. virginiana accessions PI 612323 and PI 612325, F. chiloensis PI 511736, and the selections FL 10-128 and FL 10-129) exhibited 100\% survival during both seasons. Despite having no collapsed plants, inspection of the crowns revealed that all of these genotypes had small necrotic lesions that, in most cases, covered less than 5\% of the internal crown tissues, although with some having more extensive lesion coverage. For the UF breeding selections, small lesions were more frequent on plants of FL 10-129 (31/40 plants; both seasons combined) than for FL 10-128 (15/40 plants), with 8 and 25 crowns, respectively, showing no visible necrosis. Few crowns of PI 612323 (7/40) and PI 612325 (1/40 plants) exhibited crown lesions but the majority exhibited no necrosis (27 and 37, respectively). Accession PI 511736 had 18/39 plants with, at most, $5 \%$ crown necrosis, and 15 plants showed no visible necrosis in the crowns. The remaining crowns sampled for these three accessions had lesions covering $25 \%$ or more of the crown tissue.

Crown resistance. Disease progress was more rapid for the first experiment, with most plants of Strawberry Festival, Camarosa, and Treasure collapsing 26 dai, whereas it took 52 dai to achieve a similar level of plant collapse during the second experiment. The analysis revealed strong $(P<0.001)$ genotype and inoculation method effects but no significant interaction $(P=0.37)$. Also, there were no significant interactions across experiment replications and genotype $(P=0.27)$ or inoculation method $(P=0.78)$. Mean genotype mortality for the injection method was 0.7 to $97 \%$, whereas it was 0 to $75 \%$ for the spray method (Fig. 1). The positions of the genotypes according to their mortality percentages, as suggested by the lack of genotype-inoculation method interaction, were similar for both inoculation methods: Camarosa, Strawberry Festival, and Treasure had the highest mortality percentages whereas UF breeding selections FL 10-128 and FL 10129 had the lowest mortality. Camarosa, Strawberry Festival, and Treasure were not different from each other when compared within inoculation methods. However, Strawberry Festival was not different from PI 612486 or Florida Elyana when the crowns were injected. The UF selections FL10-128 and FL 10-129 were clearly more resistant than the other five genotypes regardless of the inoculation method.

In both experiments, the susceptible cultivars Camarosa and Strawberry Festival (Fig. 2A) began exhibiting symptoms of collapse as quickly as 7 dai when injected. Inspection of the crowns 10 dai during follow-up inoculations showed reddish pigmentation caused by fungal colonization near the injection lesion (Fig. 2B). Breeding selections FL 10-128 and FL 10-129 (Fig. 2C and D) did not show external symptoms, and the crowns did not show visible symptoms of infection at this time. When spray inoculated, plants of Camarosa and Strawberry Festival were the first to show CCR symptoms but later than when injected, at 12 dai. Most plants of FL 10-128 and FL 10-129 survived until the end of the experiments, and the crowns were evaluated for internal symptoms. Similar to the observations from the field experiments, crowns of both genotypes had necrotic tissue. The incidence of crowns with necrotic tissue appeared to be higher in plants within which the pathogen was injected than those that were spray inoculated. When injected, 11/25 plants of FL 10-129 had necrosis whereas only $2 / 25$ of spray-inoculated plants had necrosis. For FL 10-128, 19 and 5 of 25 plants had necrosis when injected or sprayed, respectively. On both genotypes, however, most plants exhibited less than $10 \%$ crown necrosis. For PI 612486, the injection method resulted in $80 \%$ of plants collapsed, compared with $48 \%$ collapse when spray inoculated.

\section{Discussion}

Resistance to CCR is a desirable trait in strawberry that would reduce plant mortality during fruit production and breeding operations in Florida. Similarly, production of transplants in nurseries located in the southern United States would benefit from this trait. In this evaluation, higher mortality rates due to CCR were observed in the 2012-13 than in the 2013-14 season, which could be explained by warmer temperatures early in the 2012-13 season that favored symptom development (22). Weather data collected from a station located at about $150 \mathrm{~m}$ from the evaluation field showed that the lowest and highest temperatures during December and January, when averaged weekly, were 14.7 and $21.0^{\circ} \mathrm{C}$ in $2012-13$ and 11.5 and $15.8^{\circ} \mathrm{C}$ in $2013-14$, respectively (10). Several genotypes were identified among 28 octoploid Fragaria accessions with low mortality caused by CCR. However, multiple inoculations of FL 10-128 and FL 10-129 have demonstrated that a high level of resistance can be found in cultivated germplasm. Thus, introducing resistance from noncultivated accessions may not be necessary, though this may still be a desirable strategy if the wild forms contain novel sources and mechanisms of resistance. In addition, many of the supercore accessions are being utilized to improve other traits in the UF and other breeding programs $(13,14)$. Thus, the information gained in this study can be used to further refine strategies for utilizing wild accessions in strawberry improvement. For instance, PI 612498, PI 612499, and PI 612495 have been utilized in crosses, in part due to their remontant flowering and heat tolerance, but the latter accession appears to be very susceptible to CCR and may be deprioritized for that reason.

The five genotypes that had no plant collapse during both seasons (FL 10-128, FL 10-129, PI 612323, PI 612325, and PI 511736) might be beneficial as sources of genetic variability for resistance to CCR. The breeding selections FL 10-128 and FL 10-129 were chosen from a cooperative study between NCSU and UF evaluating genetic parameters for resistance to CCR (26). One of the parents of FL 10-128 is 'Pelican', a cultivar released in 1996 and obtained from a multi-institutional effort to develop cultivars resistant to anthracnose (31). At release, Pelican was described as resistant to crown rots caused by $C$. acutatum and $C$. fragariae and root rot caused by five races of Phytophthora fragariae (31) and, later, as resistant to $C$. gloeosporioides (21). FL 10-129 was obtained 
from a cross between NCH 09-68 (an NCSU selection) and 'Winter Dawn', both of which have resistance to $C$. gloeosporioides. The original sources of resistance in Winter Dawn are not known; however, NCH 0968 has PI 612486 in its pedigree (26), which appears to have some level of resistance to the pathogen (Tables 1 and 2; Fig. 1). In the field evaluation, FL 10-128 and FL 10-129 had plants with small necrotic crown lesions; however, most lesions did not extend further than the apical meristem of newly forming crowns and had well-delimited borders,

Table 1. Mean percent mortality and area under the disease progress curve (AUDPC) values for plant collapse caused by Colletotrichum crown rot in a field study of 34 Fragaria genotypes inoculated with Colletotrichum gloeosporioides during the 2012-13 Florida strawberry season ${ }^{2}$

\begin{tabular}{|c|c|c|c|c|c|c|c|c|c|c|c|}
\hline \multirow[b]{2}{*}{ PI } & \multirow[b]{2}{*}{ Genotype } & \multicolumn{5}{|c|}{ Standard cultivar } & \multicolumn{5}{|c|}{ Standard cultivar } \\
\hline & & $\begin{array}{c}\text { Mortality } \\
(\%)\end{array}$ & $\begin{array}{l}\text { Florida } \\
\text { Elyana }\end{array}$ & Treasure & Camarosa & $\begin{array}{l}\text { Strawberry } \\
\text { Festival }\end{array}$ & AUDPC & $\begin{array}{l}\text { Florida } \\
\text { Elyana }\end{array}$ & Treasure & Camarosa & $\begin{array}{c}\text { Strawberry } \\
\text { Festival }\end{array}$ \\
\hline \multirow{2}{*}{$\begin{array}{l}\cdots \\
\cdots\end{array}$} & FL10-128 & 0.0 & NS & $*$ & $*$ & $*$ & 0.0 & NS & $*$ & $*$ & $*$ \\
\hline & FL10-129 & 0.0 & NS & $*$ & $*$ & $*$ & 0.0 & NS & $*$ & $*$ & $*$ \\
\hline 551736 & $\begin{array}{l}\text { Fragaria chiloensis } \\
\text { subsp. } c \text {. forma } c \text {. }\end{array}$ & 0.0 & NS & $*$ & $*$ & $*$ & 0.0 & NS & $*$ & * & $*$ \\
\hline 612320 & $\begin{array}{l}\text { F. virginiana subsp. } \\
\text { grayana JP 95-9-6 }\end{array}$ & 0.0 & NS & $*$ & $*$ & $*$ & 0.0 & NS & $*$ & $*$ & $*$ \\
\hline 612323 & F. virginiana $\mathrm{NC}$ 96-35-2 & 0.0 & NS & $*$ & $*$ & $*$ & 0.0 & NS & $*$ & $*$ & $*$ \\
\hline 612325 & F. virginiana $\mathrm{NC} 96-5-3$ & 0.0 & NS & $*$ & $*$ & $*$ & 0.0 & NS & $*$ & * & $*$ \\
\hline 612499 & $\begin{array}{l}\text { F. virginiana subsp. } \\
\text { virginiana } \mathrm{RH} 30\end{array}$ & 5.0 & NS & NS & $*$ & $*$ & 0.2 & NS & NS & $*$ & $*$ \\
\hline 612501 & $\begin{array}{l}\text { F. virginiana subsp. } \\
\text { virginiana } \text { LH 30-4 }\end{array}$ & 5.0 & NS & NS & $*$ & $*$ & 1.9 & NS & NS & $*$ & $*$ \\
\hline$\ldots$ & Florida Elyana & 8.3 & $\ldots$ & NS & $*$ & $*$ & 2.0 & - & NS & $*$ & $*$ \\
\hline 612486 & $\begin{array}{l}\text { F. virginiana subsp. } \\
\text { grayana NC 95-19-1 }\end{array}$ & 10.0 & NS & NS & $*$ & $*$ & 5.6 & NS & NS & $*$ & $*$ \\
\hline 612324 & F. virginiana NC 96-48-1 & 10.0 & NS & NS & $*$ & $*$ & 9.4 & NS & NS & $*$ & $*$ \\
\hline 612570 & $\begin{array}{l}\text { F. virginiana subsp. } \\
\text { grayana JP 95-1-1 }\end{array}$ & 15.0 & NS & NS & $*$ & $*$ & 9.3 & NS & NS & $*$ & $*$ \\
\hline 612498 & $\begin{array}{l}\text { F. virginiana subsp. } \\
\text { virginiana } \mathrm{RH} 23\end{array}$ & 25.0 & NS & NS & $*$ & $*$ & 2.6 & NS & NS & * & $*$ \\
\hline$\ldots$ & Treasure & 30.0 & NS & $\ldots$ & $*$ & $*$ & 5.2 & NS & $\ldots$ & $*$ & $*$ \\
\hline 612493 & $\begin{array}{l}\text { F. virginiana } \text { subsp. } \\
\text { virginiana } \text { Fredrick } 9\end{array}$ & 45.0 & $*$ & NS & $*$ & $*$ & 30.3 & $*$ & $*$ & $*$ & $*$ \\
\hline 612492 & $\begin{array}{l}\text { F. virginiana subsp. } \\
\text { virginiana Eagle } 14\end{array}$ & 47.5 & NS & NS & NS & $*$ & 16.7 & NS & NS & $*$ & $*$ \\
\hline 612488 & $\begin{array}{l}\text { F. chiloensis subsp. } \\
\text { pacifica BC Canada }\end{array}$ & 68.7 & $*$ & NS & NS & NS & 51.8 & $*$ & $*$ & NS & NS \\
\hline 602568 & $\begin{array}{l}\text { F. chiloensis subsp. } \\
\text { c. forma patagonica } 2\end{array}$ & 75.0 & $*$ & NS & NS & NS & 80.0 & $*$ & $*$ & NS & NS \\
\hline \multirow[t]{2}{*}{612497} & $\begin{array}{l}\text { F. virginiana subsp. } \\
\text { virginiana Montreal }\end{array}$ & 88.7 & $*$ & $*$ & NS & $*$ & 49.4 & $*$ & NS & NS & NS \\
\hline & Camarosa & 90.0 & $*$ & $*$ & $\ldots$ & NS & 68.6 & $*$ & $*$ & . & NS \\
\hline 551453 & $\begin{array}{l}\text { F. chiloensis subsp. } \\
\text { lucida Westport Light }\end{array}$ & 93.7 & $*$ & $*$ & NS & NS & 79.1 & $*$ & $*$ & NS & NS \\
\hline 612569 & $\begin{array}{l}\text { F. virginiana subsp. } \\
\text { grayana NC 95-21-1 }\end{array}$ & 95.0 & $*$ & $*$ & NS & NS & 76.8 & $*$ & $*$ & NS & NS \\
\hline 612316 & $\begin{array}{l}\text { F. chiloensis subsp. } \\
\quad \text { c. forma patagonica } 2\end{array}$ & 95.0 & $*$ & $*$ & NS & NS & 90.8 & $*$ & $*$ & NS & NS \\
\hline 612317 & $\begin{array}{l}\text { F. chiloensis subsp. } \\
\text { c. forma patagonica } 2\end{array}$ & 95.0 & $*$ & $*$ & NS & NS & 92.4 & $*$ & $*$ & $*$ & NS \\
\hline 612494 & $\begin{array}{l}\text { F. virginiana LH 5-1 } \\
\text { Black Hills South }\end{array}$ & 95.0 & $*$ & $*$ & NS & NS & 94.3 & $*$ & $*$ & $*$ & NS \\
\hline \multirow[t]{2}{*}{551471} & $\begin{array}{l}\text { F. virginiana subsp. } \\
\text { platypetala Ice }\end{array}$ & 100.0 & $*$ & $*$ & NS & NS & 48.4 & $*$ & $*$ & NS & NS \\
\hline & Strawberry Festival & 100.0 & $*$ & $*$ & NS & - & 73.1 & $*$ & $*$ & NS & $\ldots$ \\
\hline 551735 & $\begin{array}{l}\text { F. chiloensis } \\
\quad \text { introgression Auk }\end{array}$ & 100.0 & $*$ & $*$ & NS & NS & 91.3 & $*$ & $*$ & $*$ & NS \\
\hline 236579 & $\begin{array}{l}\text { F. chiloensis forma } \\
\text { patagonica Darrow } 72\end{array}$ & 100.0 & $*$ & $*$ & NS & NS & 98.0 & $*$ & $*$ & $*$ & $*$ \\
\hline 612495 & $\begin{array}{l}\text { F. virginiana LH 50-4 } \\
\text { Montana }\end{array}$ & 100.0 & $*$ & $*$ & NS & NS & 100.7 & $*$ & $*$ & * & $*$ \\
\hline 612318 & $\begin{array}{l}\text { F. chiloensis NAH } 3 \\
\text { Ecuador }\end{array}$ & 100.0 & $*$ & $*$ & NS & NS & 101.1 & $*$ & $*$ & $*$ & $*$ \\
\hline 551459 & $\begin{array}{l}\text { F. chiloensis subsp. } \\
\text { pacifica } \text { Bandon State }\end{array}$ & 100.0 & $*$ & $*$ & NS & NS & 102.2 & * & $*$ & * & $*$ \\
\hline 551445 & $\begin{array}{l}\text { F. chiloensis Redwood } \\
\text { Creek }\end{array}$ & 100.0 & $*$ & $*$ & NS & NS & 103.9 & $*$ & $*$ & $*$ & $*$ \\
\hline 552091 & $\begin{array}{l}\text { F. chiloensis subsp. } \\
\text { c. forma patagonica }\end{array}$ & 100.0 & $*$ & $*$ & NS & NS & 109.9 & $*$ & $*$ & $*$ & $*$ \\
\hline
\end{tabular}

${ }^{\mathrm{z}}$ Genotypes are compared with the standard cultivar listed at the top of the column. Within columns, an asterisk $(*)$ denotes genotypes for which the mean mortality percentage or mean AUDPC values were statistically different $(P \geq 0.05)$ than the standard cultivar whereas those followed by NS were not. Mean differences were based on Fisher's least significant difference test for mortality percentages and on orthogonal contrasts for AUDPC values. 
suggesting that growth of the pathogen was arrested within the outer layers of crown tissue.

The response of PI 511736, a Peruvian landrace, was especially noticeable because it was the only genotype among the $10 \mathrm{~F}$. chiloensis genotypes evaluated with resistance to CCR. This accession was described, among clones of South American accessions, as one of the most adapted at all locations evaluated by Hancock et al. (15). Although it did not surpass North American accessions of $F$. chiloensis

Table 2. Mean percent mortality and area under the disease progress curve (AUDPC) values for plant collapse caused by Colletotrichum crown rot in a field study of 34 Fragaria genotypes inoculated with Colletotrichum gloeosporioides during the 2013-14 Florida strawberry season ${ }^{2}$

\begin{tabular}{|c|c|c|c|c|c|c|c|c|c|c|c|}
\hline \multirow[b]{2}{*}{ PI } & \multirow[b]{2}{*}{ Genotype } & \multicolumn{5}{|c|}{ Standard cultivar } & \multicolumn{5}{|c|}{ Standard cultivar } \\
\hline & & $\begin{array}{c}\text { Mortality } \\
(\%)\end{array}$ & $\begin{array}{l}\text { Florida } \\
\text { Elyana }\end{array}$ & Treasure & Camarosa & $\begin{array}{c}\text { Strawberry } \\
\text { Festival }\end{array}$ & AUDPC & $\begin{array}{l}\text { Florida } \\
\text { Elyana }\end{array}$ & Treasure & Camarosa & $\begin{array}{c}\text { Strawberry } \\
\text { Festival }\end{array}$ \\
\hline \multirow[t]{2}{*}{$\cdots$} & FL10-128 & 0.00 & NS & $*$ & $*$ & $*$ & 0.00 & NS & $*$ & $*$ & $*$ \\
\hline & FL10-129 & 0.00 & NS & $*$ & $*$ & $*$ & 0.00 & NS & $*$ & $*$ & $*$ \\
\hline 551736 & $\begin{array}{l}\text { F. chiloensis subsp. } \\
\text { c. forma } c \text {. }\end{array}$ & 0.00 & NS & $*$ & $*$ & $*$ & 0.00 & NS & $*$ & $*$ & $*$ \\
\hline 612323 & F. virginiana $\mathrm{NC}$ 96-35-2 & 0.00 & NS & $*$ & $*$ & $*$ & 0.00 & NS & $*$ & $*$ & $*$ \\
\hline 612325 & F. virginiana $\mathrm{NC} 96-5-3$ & 0.00 & NS & $*$ & $*$ & $*$ & 0.00 & NS & $*$ & $*$ & $*$ \\
\hline 612486 & $\begin{array}{l}\text { F. virginiana subsp. } \\
\text { grayana NC } 95-19-1\end{array}$ & 0.00 & NS & $*$ & $*$ & $*$ & 0.00 & NS & $*$ & $*$ & $*$ \\
\hline 612320 & $\begin{array}{l}\text { F. virginiana subsp. } \\
\text { grayana JP 95-9-6 }\end{array}$ & 5.00 & NS & $*$ & $*$ & $*$ & 5.78 & NS & $*$ & $*$ & $*$ \\
\hline 612324 & F. virginiana $\mathrm{NC}$ 96-48-1 & 5.00 & NS & $*$ & $*$ & $*$ & 0.53 & NS & $*$ & $*$ & $*$ \\
\hline 612492 & $\begin{array}{l}\text { F. virginiana subsp. } \\
\text { virginiana Eagle } 14\end{array}$ & 5.00 & NS & $*$ & $*$ & $*$ & 0.53 & NS & $*$ & $*$ & $*$ \\
\hline 612493 & $\begin{array}{l}\text { F. virginiana subsp. } \\
\text { virginiana Fredrick } 9\end{array}$ & 5.00 & NS & $*$ & $*$ & $*$ & 1.58 & NS & $*$ & $*$ & $*$ \\
\hline 612498 & $\begin{array}{l}\text { F. virginiana subsp. } \\
\text { virginiana } \mathrm{RH} 23\end{array}$ & 5.00 & NS & $*$ & $*$ & $*$ & 1.93 & NS & $*$ & $*$ & $*$ \\
\hline 612501 & $\begin{array}{l}\text { F. virginiana subsp. } \\
\text { virginiana LH 30-4 }\end{array}$ & 10.00 & NS & $*$ & $*$ & $*$ & 1.75 & NS & $*$ & $*$ & $*$ \\
\hline 612570 & $\begin{array}{l}\text { F. virginiana subsp. } \\
\text { grayana JP 95-1-1 }\end{array}$ & 10.00 & NS & $*$ & $*$ & $*$ & 6.65 & NS & NS & $*$ & $*$ \\
\hline$\ldots$ & Florida Elyana & 15.00 & $\ldots$ & $*$ & $*$ & $*$ & 1.58 & $\ldots$ & $*$ & $*$ & $*$ \\
\hline 612499 & $\begin{array}{l}\text { F. virginiana subsp. } \\
\text { virginiana } \mathrm{RH} 30\end{array}$ & 15.00 & NS & $*$ & $*$ & $*$ & 11.38 & NS & NS & $*$ & $*$ \\
\hline 612497 & $\begin{array}{l}\text { F. virginiana subsp. } \\
\text { virginiana Montreal }\end{array}$ & 30.00 & NS & $*$ & $*$ & $*$ & 16.80 & $*$ & NS & $*$ & NS \\
\hline 612569 & $\begin{array}{l}\text { F. virginiana subsp. } \\
\text { grayana NC } 95-21-1\end{array}$ & 35.00 & NS & NS & $*$ & NS & 25.03 & NS & NS & NS & NS \\
\hline 612488 & $\begin{array}{l}\text { F. chiloensis subsp. } \\
\text { pacifica } \text { BC Canada }\end{array}$ & 36.25 & NS & $*$ & $*$ & $*$ & 30.58 & $*$ & NS & NS & NS \\
\hline 612318 & $\begin{array}{l}\text { F. chiloensis NAH } 3 \\
\text { Ecuador }\end{array}$ & 55.00 & $*$ & NS & $*$ & NS & 21.88 & $*$ & $*$ & $*$ & $*$ \\
\hline 551471 & $\begin{array}{l}F . \text { virginiana subsp. } \\
\text { platypetala Ice }\end{array}$ & 55.00 & $*$ & NS & $*$ & NS & 34.48 & $*$ & $*$ & NS & NS \\
\hline$\ldots$ & Strawberry Festival & 60.00 & $*$ & NS & $*$ & $\ldots$ & 30.10 & $*$ & $*$ & NS & $\ldots$ \\
\hline$\ldots$ & Treasure & 60.00 & $*$ & $\ldots$ & $*$ & NS & 10.85 & $*$ & $\ldots$ & $*$ & $*$ \\
\hline 236579 & $\begin{array}{l}\text { F. chiloensis forma } \\
\text { patagonica Darrow } 72\end{array}$ & 60.00 & $*$ & NS & $*$ & NS & 30.80 & $*$ & $*$ & NS & NS \\
\hline 612494 & $\begin{array}{l}\text { F. virginiana } \text { LH 5-1 } \\
\text { Black Hills South }\end{array}$ & 60.00 & $*$ & NS & $*$ & NS & 40.43 & $*$ & $*$ & NS & $*$ \\
\hline 551453 & $\begin{array}{l}\text { F. chiloensis subsp. } \\
\text { lucida Westport Light }\end{array}$ & 70.00 & $*$ & NS & NS & NS & 43.40 & $*$ & $*$ & NS & NS \\
\hline 602568 & $\begin{array}{l}\text { F. chiloensis subsp. } \\
\text { c. forma patagonica } 2\end{array}$ & 80.00 & $*$ & NS & NS & NS & 40.95 & $*$ & $*$ & NS & NS \\
\hline 612316 & $\begin{array}{l}\text { F. chiloensis subsp. } \\
\quad \text { c. forma patagonica } 2\end{array}$ & 80.00 & $*$ & $*$ & NS & $*$ & 37.80 & $*$ & $*$ & NS & NS \\
\hline 551445 & $\begin{array}{l}\text { F. chiloensis Redwood } \\
\text { Creek }\end{array}$ & 80.00 & $*$ & NS & NS & NS & 45.15 & $*$ & $*$ & NS & NS \\
\hline 551735 & $\begin{array}{l}\text { F. chiloensis } \\
\text { introgression Auk }\end{array}$ & 80.00 & $*$ & NS & NS & NS & 78.75 & $*$ & $*$ & NS & $*$ \\
\hline$\ldots$ & Camarosa & 90.00 & $*$ & $*$ & $\ldots$ & $*$ & 46.90 & $*$ & $*$ & $\ldots$ & NS \\
\hline 612317 & $\begin{array}{l}\text { F. chiloensis subsp. } \\
\quad \text { c. forma patagonica } 2\end{array}$ & 90.00 & $*$ & $*$ & NS & $*$ & 82.95 & $*$ & $*$ & NS & $*$ \\
\hline 551459 & $\begin{array}{l}\text { F. chiloensis subsp. } \\
\text { pacifica } \text { Bandon State }\end{array}$ & 93.75 & $*$ & $*$ & NS & $*$ & 64.97 & $*$ & $*$ & NS & $*$ \\
\hline 552091 & $\begin{array}{l}\text { F. chiloensis subsp. } \\
\text { c. forma patagonica }\end{array}$ & 95.00 & $*$ & $*$ & NS & $*$ & 85.75 & $*$ & $*$ & $*$ & $*$ \\
\hline 612495 & $\begin{array}{l}\text { F. virginiana } \mathrm{LH} \\
\text { 50-4 Montana }\end{array}$ & 100.00 & $*$ & $*$ & NS & $*$ & 80.33 & $*$ & $*$ & NS & $*$ \\
\hline
\end{tabular}

${ }^{\mathrm{z}}$ Genotypes are compared with the standard cultivar listed at the top of the column. Within columns, an asterisk $(*)$ denotes genotypes for which the mean mortality percentage or mean AUDPC values were statistically different $(P \geq 0.05)$ than the standard cultivar whereas those followed by NS were not. Mean differences were based on Fisher's least significant difference test for mortality percentages and on orthogonal contrasts for AUDPC values. 


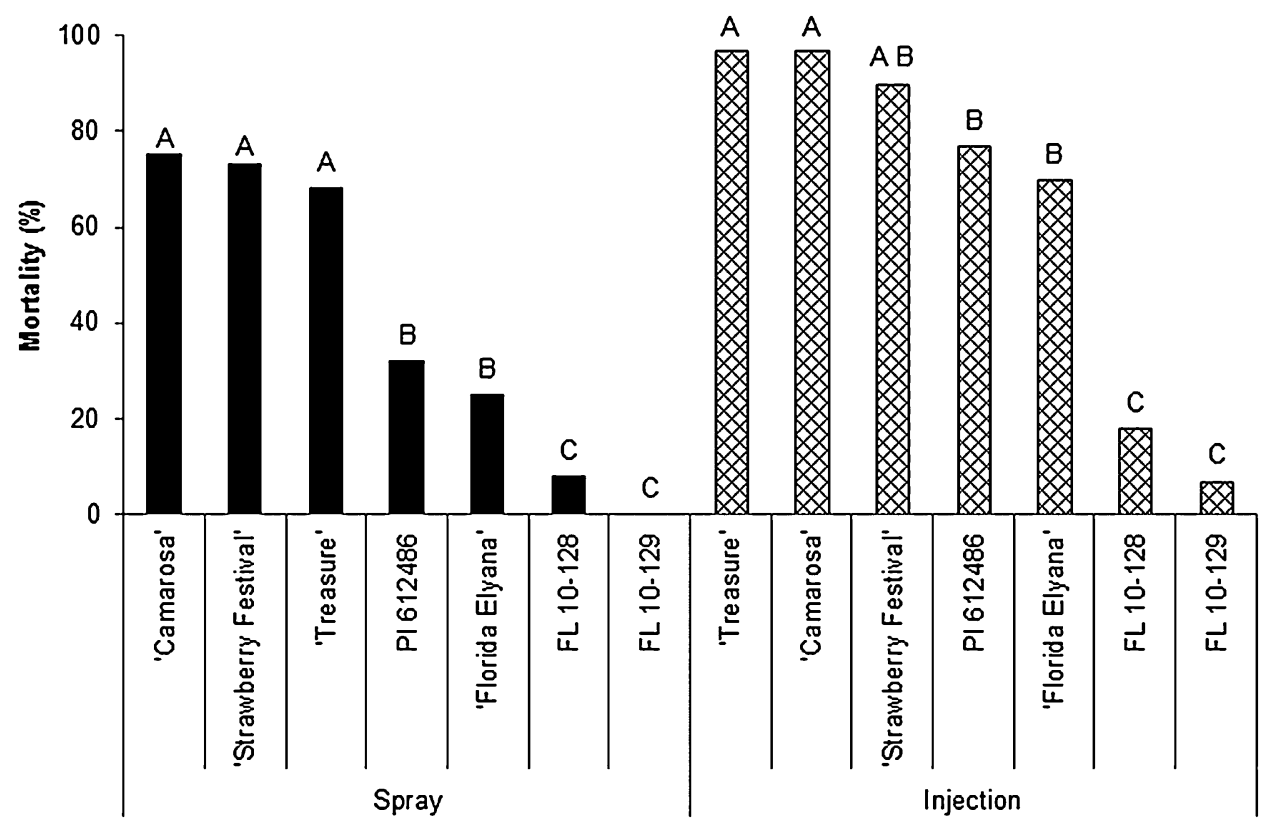

Fig. 1. Mean percent mortality of seven genotypes inoculated with a conidial suspension of Colletotrichum gloeosporioides by spray or injection methods. Mean values with the same letters were not statistically different $(P \geq 0.05)$.
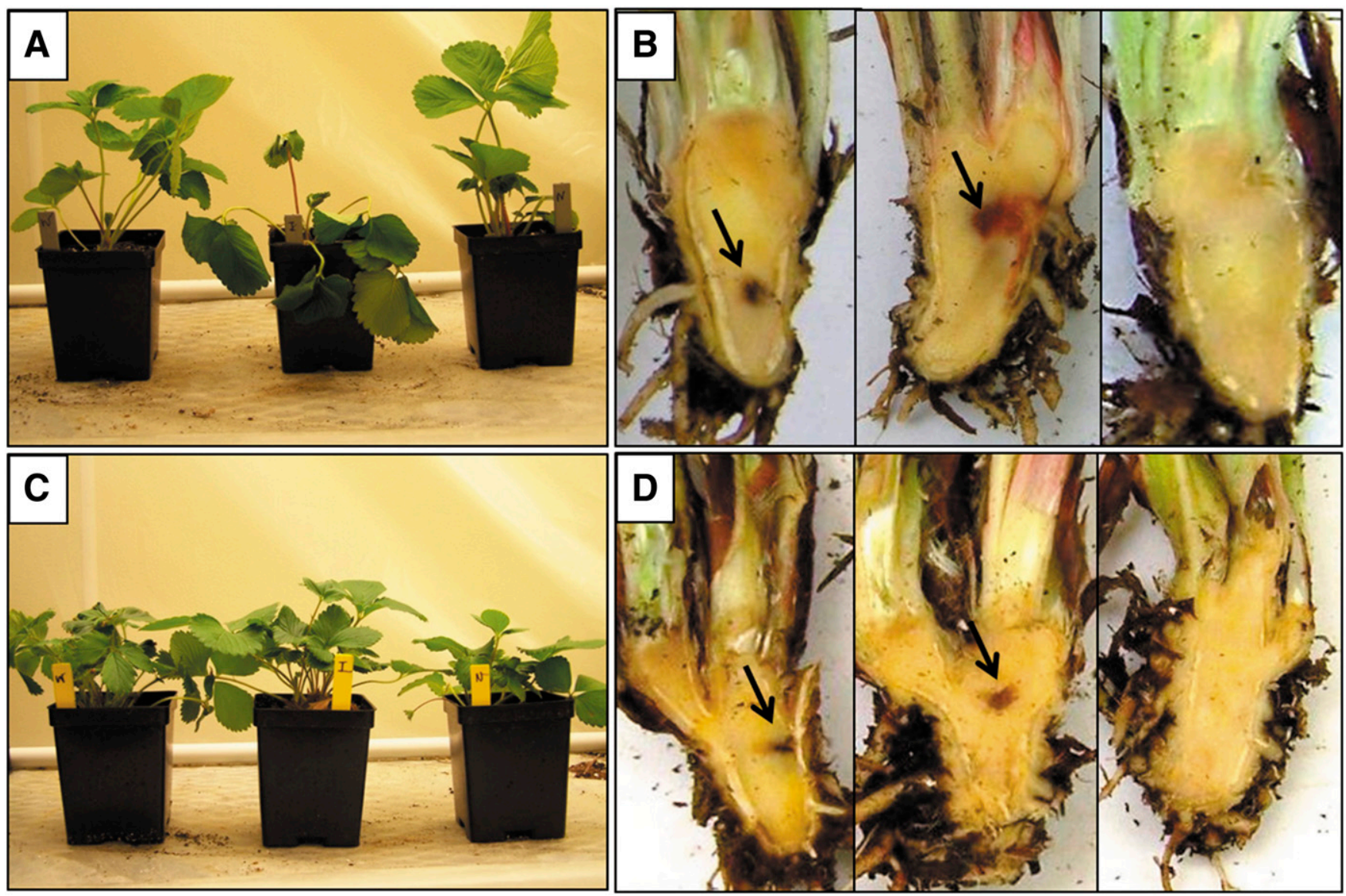

Fig. 2. Response of A and B, Strawberry Festival (susceptible) and C and D, FL 10-129 (resistant) to crown injection with a conidial suspension of Colletotrichum gloeosporioides 10 days after inoculation. Left, middle, and right portions of each panel show water-inoculated, fungal-inoculated, and noninoculated plants or crowns, respectively. Fungalinoculated plants of Strawberry Festival (A, middle) were collapsing due to crown infection whereas those of FL 10-129 (C, middle) were asymptomatic. Crown tissues of Strawberry Festival (B, middle) showed typical reddish necrosis (arrow), whereas crown tissues of FL 10-129 did not exhibit necrosis (D, middle) at 10 days after inoculation, though necrosis was observed later. Water-inoculated plants of both genotypes remained asymptomatic (A and C, left), whereas crowns showed only a small, dark lesion or wound (arrows) left by the syringe ( $B$ and $D$, left). 
in horticultural performance in their study, it produced large, goodflavored fruit. Lewers et al. (21), in their evaluation of the supercore collection for Colletotrichum resistance, reported PI 551736 as moderately susceptible to the $C$. gloeosporioides isolate utilized (average disease rating $\leq 4$ ). Their scale valued genotypes with disease ratings of 5 as those showing wilted leaves whereas genotypes with a rating of 6 would have dead plants, both of which are symptoms associated with crown infection. According to their scale description, genotypes with a disease rating $\leq 4$ had, at least, petiole lesions that were larger than $20 \mathrm{~mm}$ long; but it is unclear if any crown infection occurred on any of the plants of PI 551736 in their study. In the present study, none of the plants of this genotype collapsed and, although some foliar lesions were observed early in the season, they were not severe and no isolation was attempted. PI 551736 was among the most vegetatively robust accessions in our evaluation, forming moderately sized plants with abundant leaves, several crowns per plant, and a strong root system, similar to previous reports. After further evaluation of the crowns, 24 of 39 plants had internal necrosis. Moreover, isolations from the symptomatic tissue confirmed the presence of C. gloeosporioides. Although it is not clear whether tissues other than the crown of this accession were colonized by the inoculated isolate, it is evident that this genotype is not immune to the pathogen. Because most crowns were infected, whatever resistance mechanisms exist may act by slowing the growth of the fungus within crown tissue rather than preventing initial stages of infection.

Of the two $F$. virginiana accessions that had $100 \%$ survival on both seasons, only PI 612323 was evaluated by Lewers et al. (21) and it was categorized as resistant to the C. gloeosporioides isolate inoculated. In that study, PI 612323 had lower average disease rating $(\leq 2)$ than PI 511736, meaning it had petiole lesions between 3 and $10 \mathrm{~mm}$ long. According to Hancock et al. (15), this genotype was also vigorous and formed dense plants. In our evaluation, plants of this genotype also formed a dense canopy but were smaller and had fewer crowns compared with those of PI 511736. Information on the accession PI 612325 was not available in the two studies previously mentioned but, in our evaluation, it showed a growth pattern similar to PI 612323. Both of these genotypes are representative of $F$. virginiana from the southern United States and were collected in North Carolina (15), which could explain the similarity of their performance. Also, the incidence and severity of necrosis in the crowns of these genotypes was similar to that observed on the FL 10-128 and FL 10-129 selections, raising the possibility that one or more mechanisms of resistance could be similar among these genotypes.

Discrepancies in the classification of genotypes among different inoculation studies could be attributed to differences in the isolates tested. In fact, it has been suggested that $C$. gloeosporioides is a complex of morphologically similar species. A recent study utilized multiple genetic relationships to differentiate the species within this complex and showed that isolates recovered from strawberry crowns previously classified as C. gloeosporioides were found to be genetically related to $C$. siamense and $C$. fruticola (35). Accurate identification of the pathogen is then important to determine response to infection and resistance mechanisms. For instance, crown infections caused by C. acutatum do not result in sudden wilt like those caused by $C$. gloeosporioides and $C$. fragariae; however, they cause a decrease in plant vigor and stunting (33). Moreover, multiple races of $C$. fragariae have been reported $(17,30)$ whereas resistance to $C$. gloeosporioides appears to be race nonspecific (22). Because these studies suggest that resistance mechanisms against the three species may be different, evaluation of genotypes under the same conditions and focusing on crown responses may be necessary to determine whether resistance against these species is correlated. Even within the same species complex, isolates may differ in their levels of aggressiveness. Differences in aggressiveness were observed in a study using $C$. gloeosporioides isolates recovered from strawberry crowns in different years. Various commercial cultivars were inoculated separately with these isolates to evaluate CCR during three seasons from 2001 to 2004 (22). Although all isolates were not used in each season, those that were used more than once differed in aggressiveness. The Florida isolate $97-15 \mathrm{~A}$ was the most aggressive evaluated in the 2001-02 strawberry season.
Although classification of the genotypes into resistant and susceptible genotypes in the present study may not be similar the classification of Lewers et al. (21), it is important to note that differences also may be a product of the disease evaluation scale used or the symptoms of the disease that were evaluated. However, taking both studies together, breeders now have more complete information with which to improve resistance to CCR in strawberry. For instance, crown infections can be caused when spores produced on petiole lesions are carried to the crown by water (18). Genotypes such as PI 612324 may possess foliar resistance, because this accession showed only small foliar lesions in Lewers et al. (21), which may reduce the probability for crown infections. During both seasons in Florida, this accession also had low mortality (10.0 and 5.0\%) and low AUDPC values ( 9.5 and 0.5 ) showing that, when mortality occurred, it occurred primarily in the latter portion of the season. In commercial fields, infected plants of moderately resistant cultivars such as Treasure usually remain asymptomatic at first; however, plant collapse occurs as temperatures increase at the end of the season (22). This trend was observed for Treasure and also other genotypes in this study. The majority of the highly susceptible genotypes in our study had both high mortality and AUDPC values, suggesting that most plants collapsed earlier in the season.

The infection processes of various Colletotrichum spp. on different hosts have been described (25) but those involving C. gloeosporioides and strawberry crowns are unknown. Although resistance to CCR in strawberry germplasm has been reported, the mechanisms involved in these responses have not been determined. We sought to evaluate strawberry cultivars and wild accessions with known response to CCR and to identify the infection processes involved in crown infection as well as potential resistance mechanisms through histological observations using GFP-expressing C. gloeosporioides. The isolate 97-15A-GFP used in this study was transformed for this purpose; however, we observed that expression of the GFP signal was not stable, affecting the consistency of microscopy observations. Nonetheless, multiple inoculation tests confirmed that pathogenicity of the GFP-expressing isolate was similar to that of the wild type (data not shown) and was used for subsequent crown inoculations.

Direct injection of the crowns with a spore suspension of the 97-15A-GFP isolate showed that resistance is expressed within crown tissues. Classification of the genotypes into susceptible and resistant groups did not change whether the plants were sprayed or injected. Thus, both inoculation methods could be utilized to determine resistance to CCR. Spraying the spore suspension on the top of strawberry crowns requires less time to perform, simulates natural infection, and may be preferred to select resistant material from a large number of genotypes. However, spray-inoculated plants collapse at a slower rate than injected plants, which may extend the period necessary for evaluation. Additionally, because the specific resistance mechanisms in crown tissues of strawberry are not understood, it is not known whether the same mechanisms are being expressed when plants are injected or sprayed. Therefore, genotypes selected from spray trials can be further evaluated by injection to identify resistance in crown tissues.

Passive and active defenses in strawberry tissues other than the crown have been identified for several pathogens (1). Although the resistance mechanisms in crowns of strawberry are still uncharacterized, it is possible that structural differences, either preformed or induced, may be involved. For instance, lignified cells form a physical barrier for penetration of fungal pathogens and lignin can also be deposited on adjacent sites to fortify other cells following pathogen infection (34). In our study, we observed that resistance to CCR may act by preventing earlier stages of infection which can be due to differences in the internal structure of crown cell layers among cultivars. Lignification may be responsible for slowing the growth of the fungus within crown tissues, as suggested by the small, delimited necrotic lesions observed in the crowns of some genotypes. The resistance response, whatever it may be, resulted in delayed plant collapse in our field trials. Under the annual strawberry production system in Florida, extending the survival of infected plants will help producers to maintain fruit production during the profitable winter growing period. 


\section{Literature Cited}

1. Amil-Ruiz, F., Blanco-Portales, R., Muñoz-Blanco, J., and Caballero, J. L. 2011. The strawberry plant defense mechanism: a molecular review. Plant Cell Physiol. 52:1873-1903.

2. Bailey, J. A., and Jeger, M. J., eds. 1992. Colletotrichum: Biology, Pathology and Control. CAB International, Wallingford, UK.

3. Campbell, C. L., and Madden, L. V. 1990. Introduction to Plant Disease Epidemiology. Wiley, New York.

4. Chandler, C. K. 2009. 'Winter Dawn' strawberry plant. U.S. plant patent no. US2009/0013438P1.

5. Chandler, C. K., Albregts, E. E., Howard, C. M., and Brecht, J. K. 1997. 'Sweet Charlie' strawberry. HortScience 32:1132-1133.

6. Chandler, C. K., Legard, D. E., Dunigan, D. D., Crocker, T. E., and Sims, C. A. 2000. 'Strawberry Festival' strawberry. HortScience 35:1366-1367.

7. Chandler, C. K., Santos, B. M., Peres, N. A., Jouquand, C., and Plotto, A. 2009. 'Florida Elyana' strawberry. HortScience 44:1775-1776.

8. Chandler, C. K., Santos, B. M., Peres, N. A., Jouquand, C., Plotto, A., and Sims, C. A. 2009. 'Florida Radiance' strawberry. HortScience 44:1769-1770.

9. Chang, P. P. 2002. Strawberry plant called 'Treasure'. U.S. plant patent no. US00PP12414P2.

10. Florida Automated Weather Network. 2014. University of Florida, Gainesville. Online publication. <http://fawn.ifas.ufl.edu/>

11. Hajjar, R., and Hodgkin, T. 2007. The use of wild relatives in crop improvement: a survey of developments over the last 20 years. Euphytica 156:1-13.

12. Hancock, J. F., Callow, P. W., Dale, A., Luby, J. J., Finn, C. E., Hokanson, S. C., and Hummer, K. E. 2001. From the Andes to the Rockies: native strawberry collection and utilization. HortScience 36:221-224.

13. Hancock, J. F., Dale, A., and Luby, J. J. 1993. Should we reconstitute strawberry? Acta Hortic. 348:86-93.

14. Hancock, J. F., Finn, C. E., Luby, J. J., Dale, A., Callow, P. W., and Serçe, S. 2010. Reconstruction of the strawberry, Fragaria $\times$ ananassa, using genotypes of $F$. virginiana and $F$. chiloensis. HortScience 45:1006-1013.

15. Hancock, J. F., Hokanson, S. C., Finn, C. E., and Hummer, K. E. 2002. Introducing a supercore collection of wild octoploid strawberries. Acta Hortic. 567:77-79.

16. Hancock, J. F., and Luby, J. J. 1993. Genetic resources at our doorstep: the wild strawberries. Bioscience 43:141-147.

17. Horn, N. L., Burnside, K. R., and Carver, R. B. 1972. Control of the crown rot phase of strawberry anthracnose through sanitation, breeding for resistance, and benomyl. Plant Dis. Rep. 56:515-519.

18. Howard, C. M., Maas, J. L., Chandler, C. K., and Albregts, E. E. 1992. Anthracnose of strawberry caused by the Colletotrichum complex in Florida. Plant Dis. 76:976-981

19. Kennedy, C., Hasing, T. N., Peres, N. A., and Whitaker, V. M. 2013. Evaluation of strawberry species and cultivars for powdery mildew resistance in open-field and high tunnel production systems. HortScience 48:1125-1129.

20. Lenne, J. M., and Wood, D. 1991. Plant diseases and the use of wild germplasm. Annu. Rev. Phytopathol. 29:35-63.
21. Lewers, K. S., Turechek, W. W., Hokanson, S. C., Maas, J. L., Hancock, J. F. Serçe, S., and Smith, B. J. 2007. Evaluation of elite native strawberry germplasm for resistance to anthracnose crown rot disease caused by Colletotrichum species. J. Am. Soc. Hortic. Sci. 132:842-849.

22. MacKenzie, S., Legard, D. E., Timmer, L. W., Chandler, C. K., and Peres, N. A. 2006. Resistance of strawberry cultivars to crown rot caused by Colletotrichum gloeosporioides isolates from Florida is nonspecific. Plant Dis. 90:1091-1097.

23. MacKenzie, S. J., Mertely, J. C., and Peres, N. A. 2009. Curative and protectant activity of fungicides for control of crown rot of strawberry caused by Colletotrichum gloeosporioides. Plant Dis. 93:815-820.

24. MacKenzie, S., and Peres, N.A. 2007. Colletotrichum crown rot (anthracnose crown rot) of Strawberry. Univ. Fla. Inst. Food Agric. Sci. PP238.

25. O'Connell, R. J., Perfect, S. E., Hughes, H. B., Carzaniga, R., Bailey, J. A., and Green, J. R. 2000. Dissecting the cell biology of Colletotrichum infection processes. Pages 57-77 in: Colletotrichum: Host Specificity, Pathology, and Host-Pathogen Interaction. D. Prusky, S. Freeman, and M. Dickman, eds. American Phytopathological Society, St. Paul, MN.

26. Osorio, L. F., Pattison, J. A., Peres, N. A., and Whitaker, V. M. 2014. Genetic variation and gains in resistance of strawberry to Colletotrichum gloeosporioides. Phytopathology 104:67-74.

27. Perez, A., and Plattner, K. 2013. Fruit and Tree Nuts Outlook No. (FTS-356) United States Department of Agriculture, Economic Research Service, Washington, DC

28. Pinkerton, J., and Finn, C. E. 2005. Responses of strawberry species and cultivars to the root-lesion and northern root-knot nematodes. HortScience 40:33-38.

29. Shah, D. A., and Madden, L. V. 2004. Nonparametric analysis of ordinal data in designed factorial experiments. Phytopathology 94:33-43.

30. Smith, B. J., and Black, L. L. 1990. Morphological, cultural, and pathogenic variation among Colletotrichum species isolated from strawberry. Plant Dis. 74:69-76.

31. Smith, B. J., Gupton, C. L., Galletta, G. J., Maas, J. L., Enns, J. M., Ballington, J. R., Jr., Constantin, R. J., DiVittorio, T. J., and Himelrick, D. 1998. 'Pelican' strawberry. HortScience 33:1082-1084.

32. Stegmeir, T. L., Finn, C. E., Warner, R. M., and Hancock, J. F. 2010. Performance of an elite strawberry population derived from wild germplasm of Fragaria chiloensis and F. virginiana. HortScience 45:1140-1145.

33. Ureña-Padilla, A. R., MacKenzie, S. J., Bowen, B. W., and Legard, D. E. 2002. Etiology and population genetics of Colletotrichum spp. causing crown and fruit rot of strawberry. Phytopathology 92:1245-1252.

34. Vance, C. P., Kirk, T. K., and Sherwood, R. T. 1980. Lignification as a mechanism of disease resistance. Annu. Rev. Phytopathol. 18:259-288.

35. Weir, B. S., Johnston, P. R., and Damm, U. 2012. The Colletotrichum gloeosporioides species complex. Stud. Mycol. 73:115-180.

36. Xiao, C. L., MacKenzie, S. J., and Legard, D. E. 2004. Genetic and pathogenic analyses of Colletotrichum gloeosporioides isolates from strawberry and noncultivated hosts. Phytopathology 94:446-453. 